\title{
Scytalidium lignicola causando Manchas em Folhas, Hastes e Frutos de Baunilha
}

\author{
Jaqueline R. Verzignassi ${ }^{1}$, Luiz S. Poltronieri ${ }^{1}$, Ruth L. Benchimol ${ }^{1}$ \& Mônika F. Moura ${ }^{2}$
}

${ }^{1}$ Embrapa Amazônia Oriental, Trav. Dr. Enéas Pinheiro, s/nº, CEP 66095-100, Belém, PA, e-mail:jaque@cpatu.embrapa.br; ${ }^{2}$ Universidade Federal Rural da Amazônia, Cx. Postal 917, CEP 66077-530, Belém, PA

Autor para correspondência: Jaqueline R. Verzignassi

\begin{abstract}
Leaf, stem and fruit spots caused by Scytalidium lignicola on vanilla (Vanilla fragans)

Leaf and fruit spots caused by Scytalidium lignicola on vanilla are recorded in Northeastern Pará State, causing significant losses in vanilla crops.
\end{abstract}

Nativa do Sudeste do México, da Guatemala e de outras regiões da América Central, a baunilha é uma trepadeira pertencente à família das orquídeas e tem como maior produtor mundial a Ilha de Madagascar, com $90 \%$ da produção mundial de 1200 toneladas por ano. Seus frutos são vagens, de 20 a $25 \mathrm{~cm}$ de comprimento (http://www.todafruta.com.br, acesso em 04/11/2005) e, das suas vagens, após o processo de cura, são obtidos os cristais de vanila, dos quais são obtidas tinturas alcoólicas utilizadas como aromatizadores de medicamentos e de alimentos. Com grande utilização em gastronomia em todo o mundo, as chamadas essências naturais de baunilha alcançam, no mercado externo, valores de até U\$ 60,00 por quilo (Revista Agroamazônia, Vol.1, n.9, 2002; http://www. todafruta.com.br, acesso em 04/11/2005). No Pará, o cultivo da baunilheira é encontrado nos municípios de Tome-Açú e Castanhal, no Nordeste Paraense. Em visita efetuada a área de cultivo comercial de baunilheira no Município de ToméAçu, verificou-se lesões necróticas deprimidas e de coloração marrom escuro a negra em folhas, hastes e frutos (Figura $1 \mathrm{~A}-$ C). O material foi coletado e encaminhado ao Laboratório de Fitopatologia da Embrapa Amazônia Oriental para a verificação da etiologia da doença. Partes de tecidos lesionados foram plaqueadas em meio de cultura batata-dextrose-ágar (BDA), as quais foram mantidas em temperatura aproximada de 26 ${ }^{\circ} \mathrm{C}$, sob luz fluorescente fria, com fotoperíodo de 12 horas. Colônias inicialmente brancas tornam-se negras após seis dias ( Figura 1D) e, a partir da observação das estruturas do fungo em microscópio óptico (Figura 1E), o fungo foi identificado como Scytalidium lignicola Pesante, conforme descrição de Ellis (1971, Dematiaceous Hyphomycetes. CMI). Procedeu-se a inoculação em folhas e em hastes destacadas de planta adulta sadia, as quais foram submetidas a ferimento e inoculação do fungo sob forma de disco de micélio + meio de cultura $(0,5$ $\mathrm{cm}$ de diâmetro). O material vegetal inoculado permaneceu em câmara úmida por 24 horas e, após 48 horas da inoculação, verificaram-se os mesmos sintomas encontrados inicialmente no campo. Das lesões formadas pela inoculação artificial porções do tecido foram retiradas e colocadas em meio de cultura BDA nas mesmas condições de temperatura e umidade anteriormente descritas. Colônias idênticas às inicialmente obtidas dos sintomas das plantas oriundas do campo foram encontradas nesta etapa. Scytalidium lignicola foi também encontrado causando podridão peduncular em mangueira (Ghini \& Kimati, Summa Phytopathol. 10:79. 1984), podridão negra em raízes e em manivas de mandioca (Laranjeira et al., Fitopatol. Brás. 19:466. 1994; Poltronieri et al., Fitopatol. Bras. 23:411. 1998; Muniz et al., Summa Phytopath. 25:156. 1999) e associado a sementes de caupi (Barros et al., Congresso Brasileiro de Sementes, III:95, 1983).
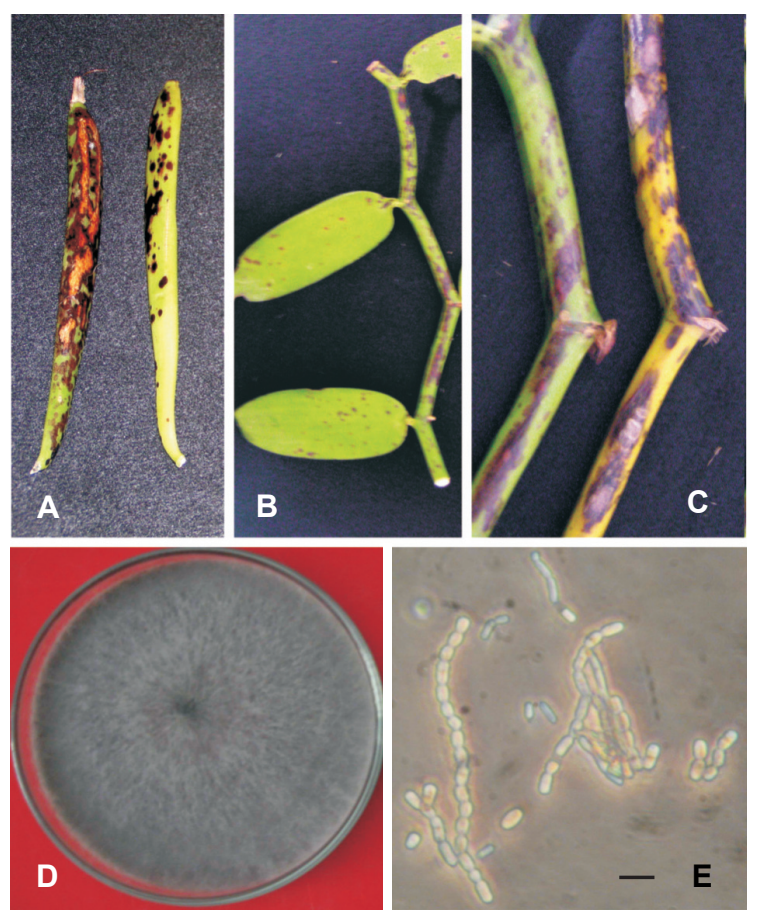

FIG. 1 - Manchas necróticas em baunilheira causadas por Scytalidium lignicola. A. frutos; B. e C. folhas e hastes; Scytalidium lignicola. D. cultura em meio BDA; E. conídios em microscópio óptico (barra $=20 \mu \mathrm{m})$. 